made to meet them until leaders in industry, commerce, politics and even education itself are better informed concerning things scientific. This can only be done by a journal which is free from scientific technicalities and jargon; and this is the style admirably adopted by The New Scientist. For the first issue, the Editor has selected some authors who are not only well known among scientists for their contributions to the advancement of science in various fields but are also able to interpret their work in an intelligible and attractive way to readers who have not been trained in scientific discipline. These authors include the President of the Royal Society (Sir Cyril Hinshelwood), Sir Edward Salisbury, Prof. Zdenek Kopal and Dr. N. A. Mackintosh. 'There are eight such articles, and each is well worth reading not only by the non-scientist but even by scientists themselves. Apparently we are also to be presented with a series of scientific profiles; Sir Edward Appleton figures in the first issue-an apt choice especially since he is giving the present series of B.B.C. Reith Lectures. Among other features of this excellent first issue are science news from the home front, from the United States and from elsewhere overseas ; letters to the Editor ; book reviews ; and city comment. This last section will appeal particularly to city business men who are specially interested in commercial and industrial projects based directly on scientific discovery.

The New Scientist has made a good start. No doubt it will maintain the high standard which it has clearly set itself, thus becoming a very important and welcome addition to British periodical literature.

\section{Numbers of Science and Technology Students in Britain}

FigURES for full-time students taking a course for a first degree in science or technology in institutions in receipt of 'Treasury grant, given by Mr. H. Macmillan in a written reply in the House of Commons on October 23, indicate that in pure science the numbers increased from 5,897 in the academic year 1938-39 to 13,916 in 1951-52 and thereafter declined slightly to 13,485 in $1953-54$. In technology the trend was the same: an increase from 3,836 in 1938-39 to 7,590 in 1951-52 and thereafter a decline to 7,439 in $1953-54$. The number of first-, secondand third-year students in pure science in 1938-39 was roughly just over 1,800 in each year, and in 1953-54 was again approximately equal -at 4,1004,300 ; but the number of fourth-year students, which rose from 396 in 1938-39 to 1,449 in 1951-52, fell to 755 in $1953-54$. In technology the variations between the different years became greater: in 1938-39 for first-, second- and third-year students the figures were $1,391,944$ and 1,193 , respectively, and in 1953-54, 2,286, 2,240 and 2,031; fourth-year students rose from 276 in $1938-39$ to 1,149 in 1951 52 , and the number in 1953-54 was 758. Students taking a fifth or later year in technology numbered 32 in $1938-39,161$ in $1952-53$, and 126 in 1953-54. An appendix to the ninth annual report of the Advisory Council on Scientific Policy since issued gives the number of first degrees in pure science in $1954-55$ as 4,938 compared with 2,167 in $1938,5,577$ in $1951-52,5,379$ in $1952-53$ and 5,096 in 1953-54. Of these, 1,886 were pass degrees ; and of the honours degrees 914 were in chemistry, 600 in physics, 494 in mathematics, 403 in biological sciences and 122 in geology and related seiences; for 1951-52, the peak year, the corresponding figures are 2,$232 ; 977$;
608 ; 553 ; 464 ; and 144, respectively. First degrees in technology in 1954-55 were 2,314 , of which 1,005 were pass degrees; for 1938-39 the corresponding figures were 1,048 and 516 ; for $195 \mathrm{l}-52,2,765$ and 1,186 ; for $1952-53,2,578$ and 1,155 ; and for 1953 $54,2,336$ and 1,036 .

\section{Patents Bill}

IN moving the second reading of the Patents Bill in the House of Lords on November 22, Lord Mancroft said that when the Patents Act, 1949, was drafted it was envisaged that, on the restoration of normal peace-time conditions, the Patent Office examiner would make his first report about three months after the complete specification was filed, and that nine months would be a reasonable allowance for the remaining steps to be taken. It was hoped that the arrears of unexamined specifications which had accumulated during the War would soon be cleared, and accordingly the average of the pre-war time limit was adopted and the period made twelve months with an optional further three months on payment of a fee. The intake of patent applications, however, is nearly 40 per cent above the pre-war average of about 21,000 , and is still increasing; and with the general shortage of science graduates the Patent Office is unable to recruit enough examiners to keep abreast of the intake. The present examining staff of about 340 (compared with 310 before the War) is expected by special efforts to dispose of nearly 26,000 complete specifications in 1956, leaving an excess of at least 3,500 on the year. There are large arrears of unexamined applications, and it is unusual for the examiner's first report on an application to go out until more than twelve months after the complete specification is filed, leaving no time for the applicant to meet any objections raised by the examiner. The Patent Office is using powers conferred on the Comptroller, under the Emergeney Act of 1939, to grant extensions, and the new Bill authorizes the Board of Trade to prescribe from time to time the period during which an application must be put in order for acceptance, subject to the limits that this period must not be less than one or more than four years. The Bill also continues the existing provision of the 1949 Act for allowing the applicant an additional three months on payment of a fee. Replying to questions about staff, Lord Mancroft said that action has been taken to attract graduates and undergraduates to a career in the Patent Office. The salary scale has been revised, and recruits now start at $£ 605$, on a scale running up to $£ 1,345$, and leading after promotion up to $£ 2,000$. Lord Mancroft added in conclusion that it is important not to lower the standard of either the examiners or the patent procedure.

\section{Grants from the R. W. Paul Instrument Fund}

THE Royal Society announces that grants have been made by the R. W. Paul Instrument Fund Committee as follows: $£ 2,000$ to Prof. R. V. Jones and Dr. A. H. S. Holbourn, University of Aberdeen, for continuation of the development of an engine for ruling diffraction gratings in which, in order to avoid the difficulty of making an almost perfect serew, use is made of light waves to determine the grating space; $£ 1,500$ to Prof. S. Devons, University of Manchester, for an investigation of the proposed optical system of a new type of reflecting camera incorporating a correcting lens and furnishing increased speed and field of view a camera which 